\title{
Aqueous Two-Phase Systems: A New Approach for the Determination of Brilliant Blue FCF in Water and Food Samples
}

\author{
Sabah Shiri, ${ }^{1}$ Tahere Khezeli, ${ }^{1}$ Shahram Lotfi, ${ }^{2}$ and Sina Shiri ${ }^{1}$ \\ ${ }^{1}$ Department of Chemistry, Faculty of Science, Payam Noor University (PNU), Tehran 19395-4697, Iran \\ ${ }^{2}$ Department of Chemistry, Faculty of Science, Payam Noor University (PNU), Gilanegharb, Iran
}

Correspondence should be addressed to Sabah Shiri; sabahshiri5@yahoo.com

Received 17 December 2011; Revised 29 April 2012; Accepted 6 May 2012

Academic Editor: Mohammad A. Al-Ghouti

Copyright (c) 2013 Sabah Shiri et al. This is an open access article distributed under the Creative Commons Attribution License, which permits unrestricted use, distribution, and reproduction in any medium, provided the original work is properly cited.

\begin{abstract}
A novel, simple, and more sensitive spectrophotometric procedure has been developed for the determination of brilliant blue FCF in water and food samples by an aqueous two-phase system (ATPS). In this method, adequate amount of polyethylene glycol/ sodium carbonate (PEG-4000/ $\mathrm{Na}_{2} \mathrm{CO}_{3}$ ) was added to aqueous solution for formation of a homogeneous solution. To the mixture solution, suitable amount of $\mathrm{Na}_{2} \mathrm{CO}_{3}$ was added, the mixture solution was shaken until the salt was dissolved, and then it was separated into two clear phases easily and rapidly. The target analyte in the water sample was extracted into the polyethylene glycol phase. After extraction, measuring the absorbance at $634 \mathrm{~nm}$ was done. The effects of different parameters such as polyethylene glycol (type and concentration), $\mathrm{pH}$, salt (type and amount), centrifuge time, and temperature on the ATPS of dye was investigated and optimum conditions were established. Linear calibration curves were obtained in the range of $0.25-750 \mathrm{ng} / \mathrm{mL}$ for brilliant blue FCF under optimum conditions. Detection limit based on three times the standard deviation of the blank $\left(3 \mathrm{~S}_{\mathrm{b}}\right)$ was $0.12 \mathrm{ng} / \mathrm{mL}$. The relative standard deviation (RSD) for $400 \mathrm{ng} / \mathrm{mL}$ was $3.14 \%$. The method was successfully applied to the determination of brilliant blue FCF in spiked samples with satisfactory results. The relative recovery was between 96.0 and $102.2 \%$.
\end{abstract}

\section{Introduction}

The goal of this work was to determine the optimal conditions for separating brilliant blue FCF by liquid-liquid extraction with PEG/salt aqueous tow-phases system.

Food dyes including Tartrazine, Quinoline Yellow, Sunset Yellow, Carmoisine, and Brilliant Blue FCF have been widely used to optimize food color, appearance, flavor, taste, and texture of many industrial food products [1,2]. Food dyes classified into natural and synthetic [3]. These additives attribute a wide range of colors such as yellow, orange, red, green, blue, purple, and brown [4]. Many of them are having enormous application in the food, pharmaceutical, tanning, paper, rubber, plastics, cosmetics, cosmetic, textile and leather industries [5-7]. However, the excess use of these substances may cause significant problems for human healthy such as cancer and others diseases $[8,9]$. Therefore, it is necessary to have efficient methodologies to control the amount of colorants in foods.
There are a lot of analytical procedures to carry out the determination of dyes in foods, such as chromatographic methods [10], high-performance liquid chromatography [11], differential pulse polarography [12], photoacoustic spectroscopy [13], and voltametric [14]. However, most of these methods are time consuming, needing a great deal of hazardous organic solvents and high cost instrumentation.

The procedures described here provide a more sensitive, fast, and simple spectrophotometry method for determination of Brilliant Blue in different food samples using an aqueous two-phase system (ATPs). Aqueous two-phase extraction has been widely used for recovery and purification of many compounds such as protein, DNA, and some cations from different matrices [15-17]. ATPS is usually composed of two or more polymer-polymer ATPS or a polymer-salt system. This selection is often ruled by economic considerations [18]. Polyethylene glycol (PEG)-potassium phosphate, and PEG and magnesium sulfate are among the most frequently used polymer-salt systems [19]. ATPSs have advantages over 
the conventional extraction systems using organic solvents (e.g., short processing time, low energy consumption, relative reliability in scaleup, and a biocompatible environment [20].

\section{Experimental}

2.1. Reagents and Instruments. PEG with molecular weight of 4000, sodium sulfate, sodium carbonate, potassium phosphate and ammonium sulfate were obtained from Merck (Darmstadt, Germany). Other reagents were of analytical grade and were purchased from Merck (Darmstadt, Germany). A stock standard solution of brilliant blue FCF(For Coloring Food) purchased from Merck (Germany) at a concentration of $0.04 \mathrm{mg} / \mathrm{L}$ was prepared. The working solutions of brilliant blue FCF were prepared by appropriate dilutions of the stock solution immediately prior to their use. All aqueous solutions were prepared with double-distilled water.

The spectrophotometer UV-Vis (model 6705, Jenway, England) was used for all the absorbance measurements with a $10 \mathrm{~mm}$ quartz cell. $\mathrm{pH}$ measurements were made with a $827 \mathrm{pH}$ meter (Metrohm, Switzerland) and equipped with a combined glass electrode. The centurion scientific centrifuge (K280R, UK) was used for centrifuging.

2.2. Experimental Method. At the beginning of the experiments, a $2 \mathrm{~mL}$ portion of the standard solution containing the brilliant blue FCF at concentration level of $40 \mathrm{ng} / \mathrm{mL}$ was placed into a $20 \mathrm{~mL}$ glass tube and adjusted $\mathrm{pH}$ to 5.5 with $9 \mathrm{~mL}$ of acetic acid/acetate buffer solution with the concentration of $0.05 \mathrm{~mol} / \mathrm{L}$. Then, $4 \mathrm{~g}(20 \% \mathrm{w} / \mathrm{w})$ of PEG 4000 and $2.5 \mathrm{~g}(12.5 \% \mathrm{w} / \mathrm{w})$ of sodium carbonate were added to it and diluted to the mark with doubled-distilled water. The mixture was shaken for $3 \mathrm{~min}$ at $35^{\circ} \mathrm{C}$ in bath water for formation of a homogeneous solution. After the mixture was centrifuged at $3500 \mathrm{rpm}$ for $10 \mathrm{~min}$. The upper phase was completely transferred to a quartz cell using a syringe. Finally, the absorbance of brilliant blue FCF extracted into the upper PEG-rich phase was measured at $634 \mathrm{~nm}$ versus reagent blank.

2.3. Sample Pretreatment Procedure. Appropriate amounts of strawberry jelly (Tehran, Iran), fruity candy (ben ben, Iran), smarties (morvarid, Iran), and smarties (mino Co, Iran) samples were dissolved in water, filtered if necessary, and diluted to $25 \mathrm{~mL}$ in a volumetric flask. An aliquot of the above solutions was treated under the general procedure for ATPS and subsequent determination of brilliant blue FCF.

\section{Results and Discussion}

In order to obtain high extraction efficiency, the effect of different parameters on extraction conditions such as salt (type and amount), polyethylene glycol (type and concentration), temperature, and $\mathrm{pH}$ of sample solution were evaluated and optimized. The optimization process was carried out

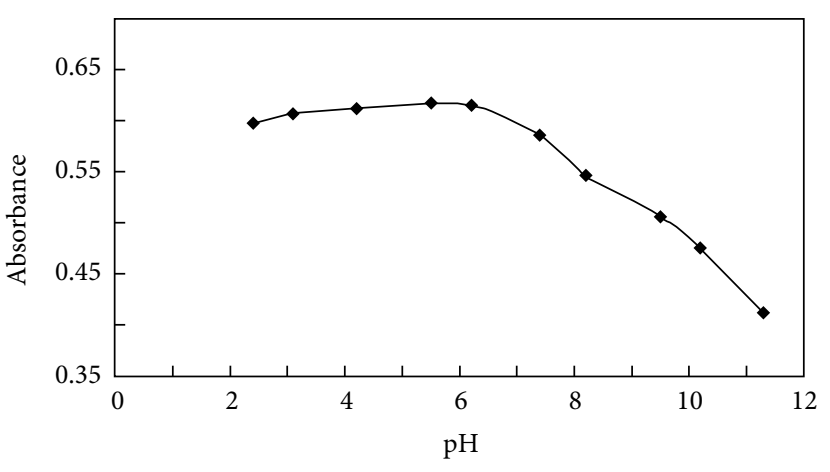

FIGURE 1: Effect of $\mathrm{pH}$ on the extraction efficiency. Experimental conditions: volume of buffer; $9 \mathrm{~mL}$, amount of PEG 4000; $4 \mathrm{gm}$, amount of sodium carbonate; $2.5 \mathrm{gm}$, temperature; $35^{\circ} \mathrm{C}$, Centrifuging time; $10 \mathrm{~min}, 4 \mathrm{ng} / \mathrm{mL}$ of brilliant blue.

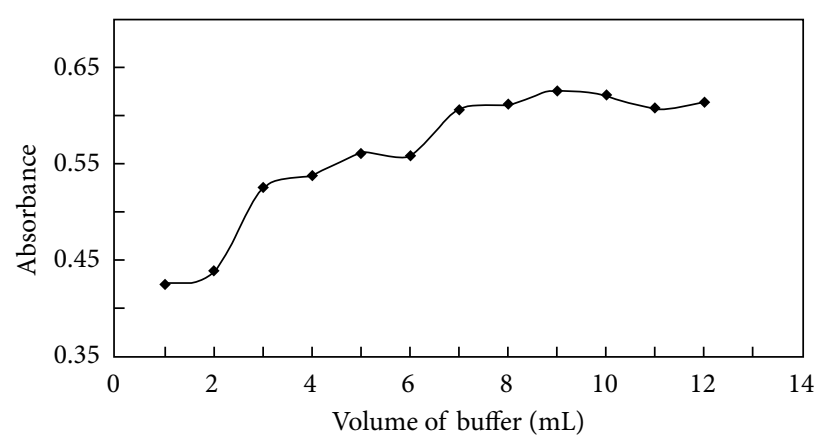

Figure 2: Effect of volume of buffer on the extraction efficiency. Experimental conditions: pH of sample; 5.5, amount of PEG 4000; $4 \mathrm{gm}$, amount of sodium carbonate; $2.5 \mathrm{gm}$, temperature; $35^{\circ} \mathrm{C}$, Centrifuging time; $10 \mathrm{~min}, 4 \mathrm{ng} / \mathrm{mL}$ of brilliant blue.

using one variable at a time method for simplifying the optimization procedure.

3.1. Effect of $\mathrm{pH}$ and Volume of Buffer. The $\mathrm{pH}$ is evaluated as a critical parameter for regulating the partitioning of the analyte in the PEG-rich phase which seems to control the extraction efficiency. Therefore, the effect of $\mathrm{pH}$ on ATPA of brilliant blue FCF from water samples was investigated. The absorbance of brilliant blue FCF was measured at $634 \mathrm{~nm}$, respectively, after performing ATPS in the $\mathrm{pH}$ range of 2.4-11.3. The $\mathrm{pH}$ of the solution was adjusted to the desired value by the addition of hydrochloric acid and sodium hydroxide and using a $\mathrm{pH}$ meter. As the results shown in Figure 1, the signal increased with the increase in $\mathrm{pH}$ from 2.4 to 5.5 , and then declined with $\mathrm{pH}$ higher than 5.5. Therefore, pH 5.5 was selected for further study. The effect of volume of the buffer on the extraction process was examined in the range of 1-12 mL. The result of Figure 2 verified that an optimum volume of buffer with $\mathrm{pH} 5.5$ has been obtained $9 \mathrm{~mL}$.

3.2. Effect of Type and Amount of PEG. We concluded the brilliant blue FCF partitioning behavior was very sensitive to changes in the PEG molecular mass. We had observed that 


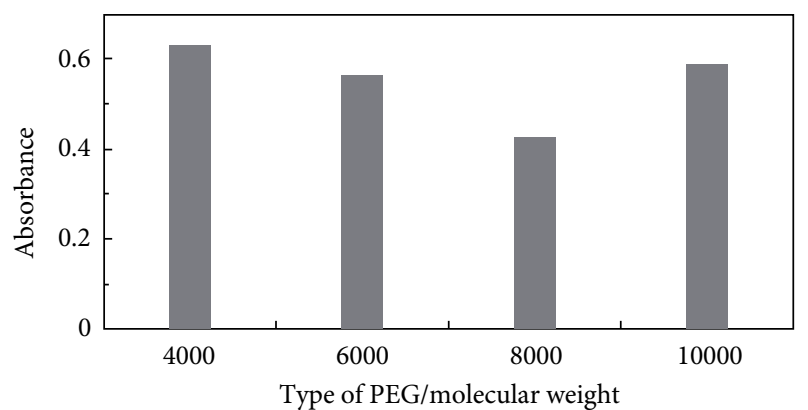

Figure 3: Effect of type of PEG on the extraction efficiency. Experimental conditions: volume of buffer; $9 \mathrm{~mL}, \mathrm{pH}$ of sample; 5.5, amount of PEG; 4 gr, amount of sodium carbonate; 2.5 gr, temperature; $35^{\circ} \mathrm{C}$, centrifuging time; $10 \mathrm{~min}, 4 \mathrm{ng} / \mathrm{mL}$ of brilliant blue.

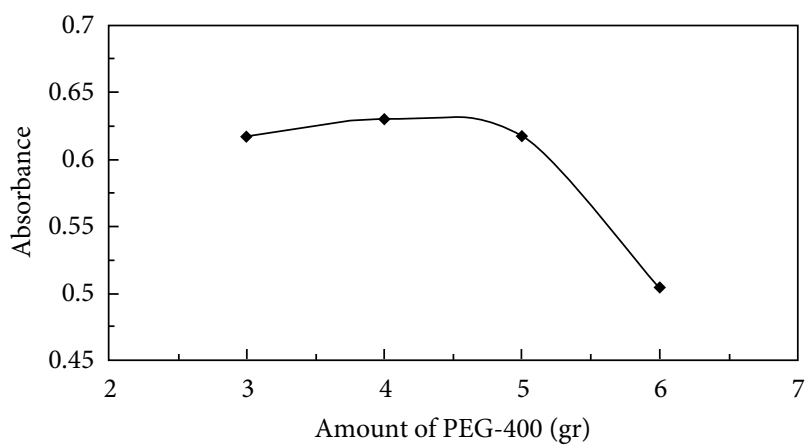

FIGURE 4: Effect of amount of PEG 4000 on the extraction efficiency. Experimental conditions: volume of buffer; $9 \mathrm{~mL}, \mathrm{pH}$ of sample; 5.5 , amount of sodium carbonate; $2.5 \mathrm{gr}$, temperature; $35^{\circ} \mathrm{C}$, centrifuging time; $10 \mathrm{~min}, 4 \mathrm{ng} / \mathrm{mL}$ of brilliant blue.

brilliant blue FCF showed a decrease in their partition coefficient value as the PEG molecular weight increased due to an increase in the polymer hydrophobic character which agrees with a general rule observed for most ATPSs [21]. Figure 3 has shown the effect of PEG with different molecular weight of $4000,6000,8000$, and 10000 . The result demonstrated that PEG-4000 higher absorption signal obtained.

The effect of the amount of PEG-4000 on the absorption was studied using various amount of the reagent ranging from $3 \mathrm{~g}$ to $6 \mathrm{~g}$, and the results were shown in Figure 4. It was found that by increasing the amount of PEG-4000, the analytical signal increased, reaching a maximum value at $4 \mathrm{~g}$, and then decreased. According to this result, all further experiments were carried out at the amount of $4 \mathrm{~g}$ of PEG $4000(20 \% \mathrm{w} / \mathrm{w})$.

3.3. Effect of Type of Salt and Amount of Salt. The influence of the ionic strength was also investigated in many techniques of liquid-liquid extraction. The electrolytes play an important role on the ATPS of nonionic surfactant systems. When small amounts of inorganic salts are added to the system, a decrease in the ATPS of PEG phase is noted. This fact indicates that it is necessary to consider the secondary effect of the electrolytes, that is, salting-out. For investigating the influence of ionic

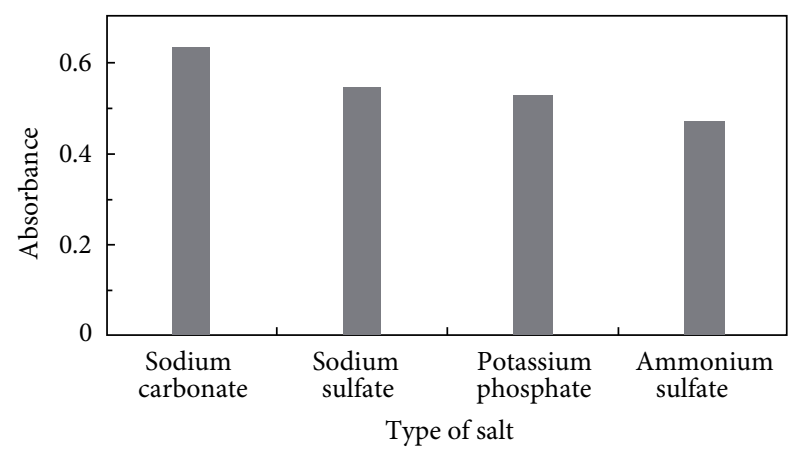

FIGURE 5: Effect of type of salt on the extraction efficiency. Experimental conditions: volume of buffer; $9 \mathrm{~mL}, \mathrm{pH}$ of sample; 5.5 , amount of PEG 4000; 4 gr, amount of salt; 2.5 gr, temperature; $35^{\circ} \mathrm{C}$, centrifuging time; $10 \mathrm{~min}, 4 \mathrm{ng} / \mathrm{mL}$ of brilliant blue.

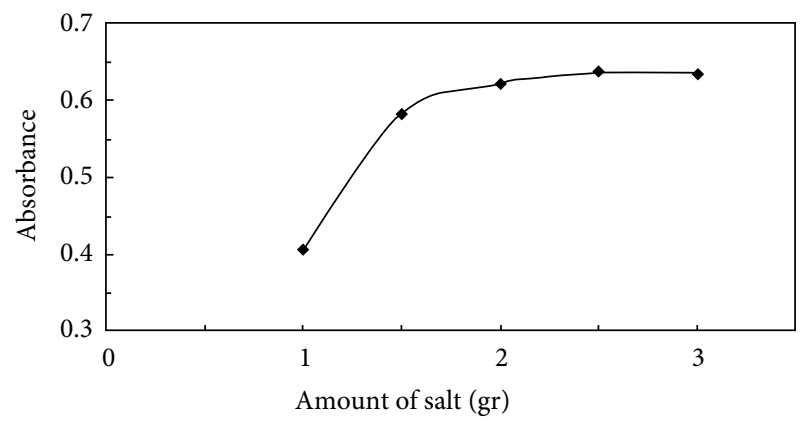

FIGURE 6: Effect of amount of salt on the extraction efficiency. Experimental conditions: volume of buffer; $9 \mathrm{~mL}, \mathrm{pH}$ of sample; 5.5 , amount of PEG $4000 ; 4$ gr, temperature; $35^{\circ} \mathrm{C}$, centrifuging time; $10 \mathrm{~min}, 4 \mathrm{ng} / \mathrm{mL}$ of brilliant blue.

strength on performance of ATPS, various experiments were performed by adding different salt such as sodium sulfate, sodium carbonate, potassium phosphate, and ammonium sulfate. The results demonstrated that sodium carbonate provided the higher signal absorption than other salts. Hence, sodium carbonate was chosen as the most appropriate salt for subsequent experiments (see Figure 5). Effect of amount of sodium carbonate on the extraction of brilliant blue FCF was investigated in the range of $1-3 \mathrm{~g}$. The differences observed in the signals at various amount of sodium carbonate are shown in Figure 6. According to this result, all further experiments were carried out at the optimum amount of $2.5 \mathrm{~g}(12.5 \% \mathrm{w} / \mathrm{w})$ of sodium carbonate.

3.4. Effect of Temperature. Temperature affects the mass transfer process and the extraction efficiency. To determine the influence of the extraction temperature, $20 \mathrm{~mL}$ aqueous solution containing $4 \mathrm{ng} / \mathrm{mL}$ of brilliant blue FCF was extracted at different temperatures ranging from $30^{\circ} \mathrm{C}$ to $50^{\circ} \mathrm{C}$. The absorption scales are almost decreased Figure 7 shows the absorbance of brilliant blue FCF as a function of temperature. Accordingly with these results, the temperature 


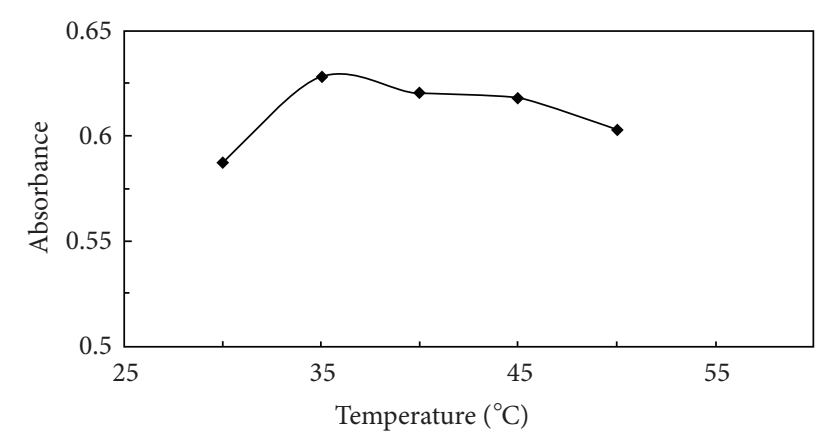

Figure 7: Effect of temperature on the extraction efficiency. Experimental conditions: volume of buffer; $9 \mathrm{~mL}, \mathrm{pH}$ of sample; 5.5 amount of PEG 4000; 4 gr, amount of sodium carbonate; $2.5 \mathrm{gr}$, Centrifuging time; $10 \mathrm{~min}, 4 \mathrm{ng} / \mathrm{mL}$ of brilliant blue.

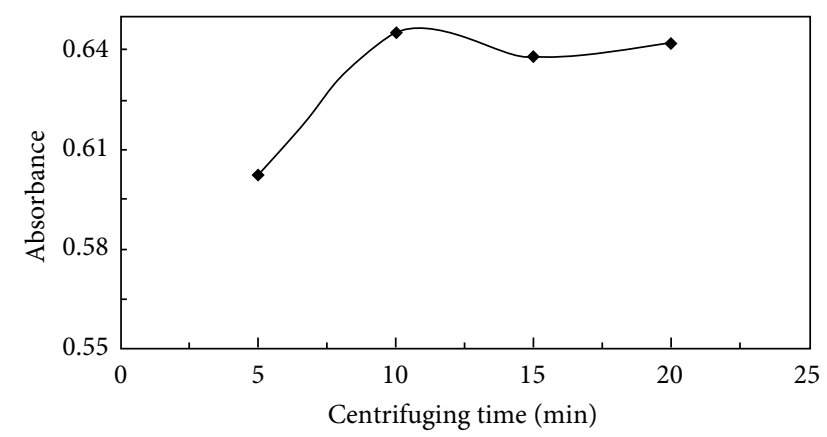

FIGURE 8: Effect of centrifuging time at $3500 \mathrm{rpm}$ on the extraction efficiency. Experimental conditions: volume of buffer; $9 \mathrm{~mL}, \mathrm{pH}$ of sample; 5.5, amount of PEG 4000; $4 \mathrm{gr}$, amount of sodium carbonate; $2.5 \mathrm{gr}$, temperature; $35^{\circ} \mathrm{C}, 4 \mathrm{ng} / \mathrm{mL}$ of brilliant blue.

that gave the best results for the majority of the target analyte was $35^{\circ} \mathrm{C}$.

3.5. Centrifuging Time. Centrifugation controls the phase separation and is a crucial step in aqueous two phase system method, and the final performance would benefit from a full phase separation. After centrifugation, the volume of PEG4000 was very small when the centrifuging time was too short, and longer centrifuging time resulted in heat generation, leading to the dissolving of parts of the PEG- 4000 phase and to the loss of sensitivity. As can be seen from Figure 8, 10 min was the optimal centrifuging time. the centrifuging time was increase partition coefficient, purification factor, efficiency and signal.

3.6. Effect of Coexisting Ions. Interferences were studied in the presence of a constant concentration of brilliant blue FCF $(4 \mathrm{ng} / \mathrm{mL})$ and different amounts of foreign cations and anions under the recommended conditions. The tolerance limits of a foreign species are shown in Table 1 . The tolerance level was defined as the maximum concentration of the foreign ion causing a change in the analytical signal no higher
TABLE 1: Effect of interference on extraction and determination of brilliant blue FCF.

\begin{tabular}{|c|c|}
\hline Foreign species & $\begin{array}{c}\text { Tolerance limit } \\
(\mathrm{ng} / \mathrm{mL})\end{array}$ \\
\hline Glucose, lactose, $\mathrm{Cl}^{-}$ & 1000 \\
\hline Folic vitamin $\mathrm{C}$, vitamin $\mathrm{A}, \mathrm{NO}^{3-}$ & 700 \\
\hline $\mathrm{Zn}^{2+}$, citrate & 600 \\
\hline Oxalate, tartarate, vitamin D & 500 \\
\hline $\mathrm{NH}^{4+}, \mathrm{Mg}^{2+}, \mathrm{F}^{-}, \mathrm{K}^{+}, \mathrm{Cu}^{2+}, \mathrm{Fe}^{2+}, \mathrm{Ca}^{2+}$ & 300 \\
\hline Vitamin $\mathrm{B}_{1}, \mathrm{PO}_{4}{ }^{2-}, \mathrm{Fe}^{3+}, \mathrm{Cd}^{2+}, \mathrm{SO}_{4}{ }^{2-}$ & 60 \\
\hline Vitamin $\mathrm{B}_{12}$, vitamin $\mathrm{B}_{6}$ & 10 \\
\hline $\mathrm{I}^{-}$, Ascorbic acid & 3 \\
\hline
\end{tabular}

than $5 \%$, when compared with the signal of $4 \mathrm{ng} / \mathrm{mL}$ brilliant blue FCF alone. As it is observed most of the ions tested do not have significant effect on the determination of brilliant blue FCF.

3.7. Analytical Figures of Merit. Important parameters such as the linear range, calibration graph, precision, detection limit, and recoveries were determined to evaluate the method performance. Under the above-optimized conditions, the calibration graph was linear in the range of $0.25-750 \mathrm{ng} / \mathrm{mL}$ with a correlation coefficient $\left(R^{2}\right)$ of $0.9995(n=8)$ of brilliant blue FCF. The relative standard deviation (RSD) for eight replicates of $400 \mathrm{ng} / \mathrm{mL}$ brilliant blue FCF was 3.14\%.

The lower limit of detection for brilliant blue FCF is defined as the concentration of analyte which gives a signal $3 \sigma$ above the mean blank signal (where $\sigma$ is the standard deviation of the blank signal). The LLOD for brilliant blue FCF was found to be $0.12 \mathrm{ng} / \mathrm{mL}$.

3.8. Application of Real Samples. To validate the proposed method, brilliant blue FCF contents in water and food samples were analyzed. Table 2 summarizes the average recovery of brilliant blue FCF in the fortified samples. Water and food samples were spiked with 10 and $40 \mathrm{ng} / \mathrm{mL}$ of standard solution of brilliant blue FCF. As can be seen in Table 2 , recoveries were more than $96.0 \%$. The result indicated that the proposed method was applicable for quantitative determination of brilliant blue FCF in real samples.

Characteristics of the proposed method have been also compared with other methods which were used for the determination of brilliant blue FCF. Table 3 compares the lower limit of detection (LLOD), relative standard deviation (RSD), linear range (LR), recovery and correlation coefficient $\left(R^{2}\right)$ of this work with cloud point extraction [3], microemulsion-modified-zeolit [8], flow injection method [8], light-emitting diode [12], and reversed-phase highperformance liquid chromatography (RP-HPLC) [16]. As can be seen, the proposed method provides similar quantification extraction efficiency, with advantages such as good linearity and correlation coefficient than many of the mentioned 
TABLE 2: Determination of brilliant blue FCF in water and food samples by the proposed aqueous two-phase system $(n=3)$.

\begin{tabular}{|c|c|c|c|c|}
\hline Sample & Added $(\mathrm{ng} / \mathrm{mL})$ & Found $\pm \mathrm{SD}^{a}(\mathrm{ng} / \mathrm{mL})$ & RSD \% & Recovery \% \\
\hline \multirow{3}{*}{ Smarties morvarid (mino CO) } & 0 & $25.1 \pm 1.2$ & 4.3 & - \\
\hline & 10 & $34.8 \pm 1.7$ & 4.8 & 97.0 \\
\hline & 40 & $64.3 \pm 3.8$ & 5.9 & 98.0 \\
\hline \multirow{3}{*}{ Fruity candy (ben ben) } & 0 & $32.1 \pm 1.4$ & 4.3 & - \\
\hline & 10 & $42.2 \pm 1.8$ & 4.2 & 101.0 \\
\hline & 40 & $73.0 \pm 2.1$ & 2.8 & 102.2 \\
\hline \multirow{3}{*}{ Strawberry jelly } & 0 & $23.8 \pm 0.7$ & 2.9 & - \\
\hline & 10 & $33.7 \pm 1.4$ & 4.1 & 99.0 \\
\hline & 40 & $62.3 \pm 2.3$ & 3.7 & 96.3 \\
\hline \multirow{3}{*}{ Water } & 0 & 0.0 & 3.6 & - \\
\hline & 10 & $9.6 \pm 0.2$ & 2.1 & 96.0 \\
\hline & 40 & $40 \pm 1.8$ & 4.5 & 100.0 \\
\hline
\end{tabular}

Standard deviation.

TABLE 3: Comparison of different methods for the determination of brilliant blue FCF by aqueous two phase system.

\begin{tabular}{lcccccc}
\hline Method & LOD & LR & RSD \% & Recovery \% & $R^{2}$ & Reference \\
\hline Cloud point extraction & $0.016 \mu \mathrm{g} / \mathrm{L}$ & $0.05-3.50 \mu \mathrm{g} / \mathrm{mL}$ & 3.3 & $>96$ & 0.9996 & {$[3]$} \\
Microemulsion & $0.35 \mathrm{mg} / \mathrm{mL}$ & $1-3 \mathrm{mg} / \mathrm{mL}$ & $<10$ & $>95.4$ & 0.9993 & {$[6]$} \\
Light emitting diode & - & $1-25 \mu \mathrm{g} / \mathrm{mL}$ & 2.8 & $>97.0$ & 0.9954 & {$[4]$} \\
HPLC & $2.72 \mu \mathrm{g} / \mathrm{L}$ & $0.008-19 \mathrm{mg} / \mathrm{mL}$ & - & - & 0.9999 & {$[1]$} \\
ATPS & $0.12 \mathrm{ng} / \mathrm{mL}$ & $0.25-750 \mathrm{ng} / \mathrm{mL}$ & $<5.9$ & $>96.0$ & 0.9995 & This work \\
\hline
\end{tabular}

techniques. Detection limit of ATPS is lower than other mentioned method.

\section{Conclusion}

The development of techniques and methods for the separation and purification of brilliant blue FCF has been an important prerequisite for many of the advancements made in the industrial food products. In our work, liquid-liquid partitioning with $\mathrm{PEG} / \mathrm{Na}_{2} \mathrm{CO}_{3}$ aqueous tow-phase system was used to selectively extract brilliant blue FCF.

In this study, a fast, simple, sensitive, and selective method named aqueous two-phase system was proposed for determination of brilliant blue FCF in water and food samples in the range of $0.25-750 \mathrm{ng} / \mathrm{mL}$. The developed ATPS was successfully applied to real system such as water and food samples analysis, indicating that the proposed method was suitable for the extraction and determination of effective component in water and food samples.

\section{Acknowledgment}

This work has been supported by the Research Council of Payam Noor University of Ilam.

\section{References}

[1] D. M. Brum, É. C. Branco de Andrade, and A. D. Pereira Netto, "Determination of synthetic dyes in selected foodstuffs by high performance liquid chromatography with UV-DAD detection,"
Food Chemistry, vol. 107, no. 1, pp. 489-496, 2008.

[2] Y. Ni, Y. Wang, and S. Kokot, "Simultaneous kinetic spectrophotometric analysis of five synthetic food colorants with the aid of chemometrics," Talanta, vol. 78, no. 2, pp. 432-441, 2009.

[3] N. Pourreza and M. Ghomi, "Simultaneous cloud point extraction and spectrophotometric determination of carmoisine and brilliant blue FCF in food samples," Talanta, vol. 84, pp. 240-243, 2011.

[4] M. H. Sorouraddin, A. Rostami, and M. Saadati, "A simple and portable multi-colour light emitting diode based photocolourimeter for the analysis of mixtures of five common food dyes," Food Chemistry, vol. 127, no. 1, pp. 308-313, 2011.

[5] A. Ergene, K. Ada, S. Tan, and H. Katircio冈lu, "Removal of Remazol Brilliant Blue R dye from aqueous solutions by adsorption onto immobilized Scenedesmus quadricauda: equilibrium and kinetic modeling studies," Desalination, vol. 249, no. 3, pp. 1308-1314, 2009.

[6] Y. S. Al-Degs, A. H. El-Sheikh, M. A. Al-Ghouti, B. Hemmateenejad, and G. M. Walker, "Solid-phase extraction and simultaneous determination of trace amounts of sulphonated and azo sulphonated dyes using microemulsion-modifiedzeolite and multivariate calibration," Talanta, vol. 75 , no. 4, pp. 904-915, 2008.

[7] T. Robinson, G. McMullan, R. Marchant, and P. Nigam, "Remediation of dyes in textile effluent: a critical review on current treatment technologies with a proposed alternative," Bioresource Technology, vol. 77, no. 3, pp. 247-255, 2001.

[8] E. C. Vidotti, W. F. Costa, and C. C. Oliveira, "Development of a green chromatographic method for determination of colorants in food samples," Talanta, vol. 68, no. 3, pp. 516-521, 2006.

[9] J. J. Berzas Nevado, C. Guiberteau Cabanillas, and A. M. Contento Salcedo, "Method development and validation for the 
simultaneous determination of dyes in foodstuffs by capillary zone electrophoresis," Analytica Chimica Acta, vol. 378, no. 1-3, pp. 63-71, 1999.

[10] M. Kucharska and J. Grabka, "A review of chromatographic methods for determination of synthetic food dyes," Talanta, vol. 80, no. 3, pp. 1045-1051, 2010.

[11] S. P. Alves, D. M. Brum, É. C. Branco de Andrade, and A. D. Pereira Netto, "Determination of synthetic dyes in selected foodstuffs by high performance liquid chromatography with UV-DAD detection," Food Chemistry, vol. 107, no. 1, pp. 489-496, 2008.

[12] S. Chanlon, L. Joly-Pottuz, M. Chatelut, O. Vittori, and J. L. Cretier, "Determination of Carmoisine, Allura red and Ponceau $4 \mathrm{R}$ in sweets and soft drinks by Differential Pulse Polarography," Journal of Food Composition and Analysis, vol. 18, no. 6, pp. 503-515, 2005.

[13] T. M. Coelho, E. C. Vidotti, M. C. Rollemberg et al., "Photoacoustic spectroscopy as a tool for determination of food dyes: comparison with first derivative spectrophotometry," Talanta, vol. 81, no. 1-2, pp. 202-207, 2010.

[14] Z. Mo, Y. Zhang, F. Zhao, F. Xiao, G. Guo, and B. Zeng, "Sensitive voltammetric determination of Sudan I in food samples by using gemini surfactant-ionic liquid-multiwalled carbon nanotube composite film modified glassy carbon electrodes," Food Chemistry, vol. 121, no. 1, pp. 233-237, 2010.

[15] I. P. Trindade, M. M. Diogo, D. M. F. Prazeres, and J. C. Marcos, "Purification of plasmid DNA vectors by aqueous two-phase extraction and hydrophobic interaction chromatography," Journal of Chromatography A, vol. 1082, no. 2, pp. 176-184, 2005.

[16] N. D. Srinivas, R. S. Barhate, and K. S. M. S. Raghavarao, "Aqueous two-phase extraction in combination with ultrafiltration for downstream processing of Ipomoea peroxidase," Journal of Food Engineering, vol. 54, no. 1, pp. 1-6, 2002.

[17] B. Jiang, Z. G. Li, J. Y. Dai, D. J. Zhang, and Z. L. Xiu, "Aqueous two-phase extraction of 2,3-butanediol from fermentation broths using an ethanol/phosphate system," Process Biochemistry, vol. 44, no. 1, pp. 112-117, 2009.

[18] C. He, S. Li, H. Liu, K. Li, and F. Liu, "Extraction of testosterone and epitestosterone in human urine using aqueous two-phase systems of ionic liquid and salt," Journal of Chromatography A, vol. 1082, no. 2, pp. 143-149, 2005.

[19] T. S. Porto, G. M. Medeiros e Silva, C. S. Porto et al., "Liquid-liquid extraction of proteases from fermented broth by PEG/citrate aqueous two-phase system," Chemical Engineering and Processing, vol. 47, no. 4, pp. 716-721, 2008.

[20] Z. Li, Y. Pei, H. Wang, J. Fan, and J. Wang, "Ionic liquid-based aqueous two-phase systems and their applications in green separation processes," Trends in Analytical Chemistry, vol. 29, no. 11, pp. 1336-1346, 2010.

[21] B. B. Nerli, M. Espariz, and G. A. Pico, "Thermodynamic study of forces involved in bovine serum albumin and ovalbumin partitioning in aqueous two-phase systems," Biotechnology and Bioengineering, vol. 72, no. 4, pp. 468-474, 2001. 

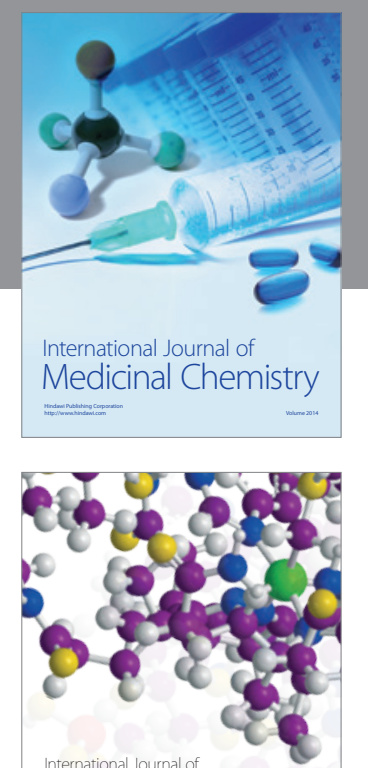

\section{Carbohydrate} Chemistry

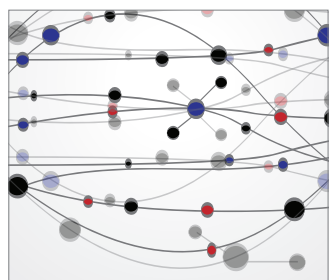

The Scientific World Journal
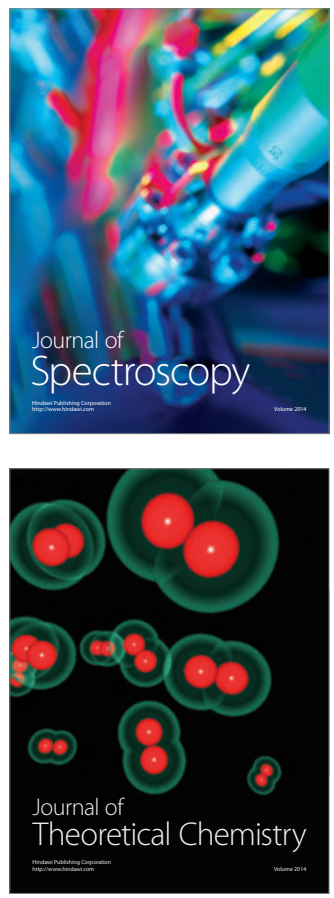
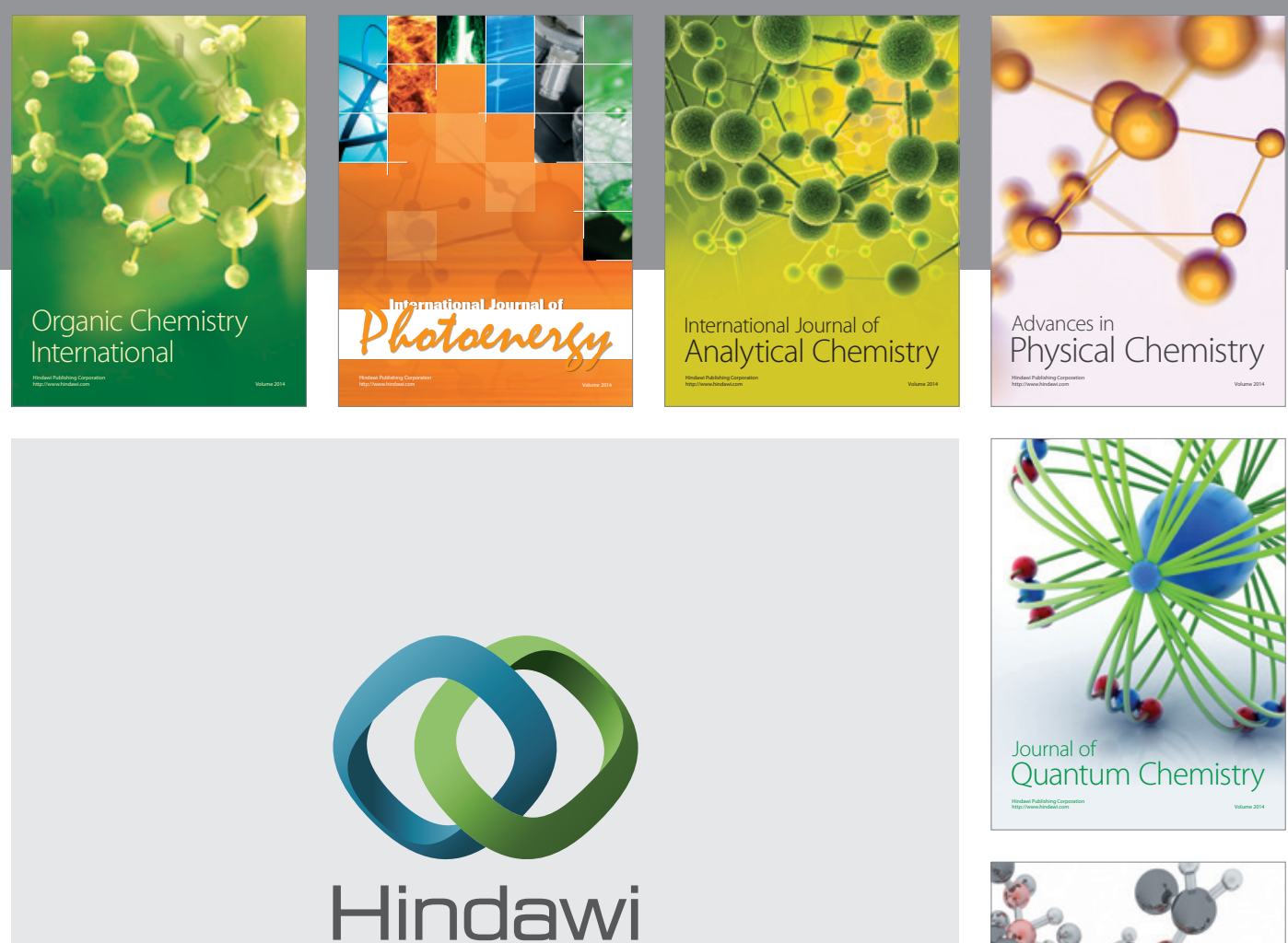

Submit your manuscripts at

http://www.hindawi.com

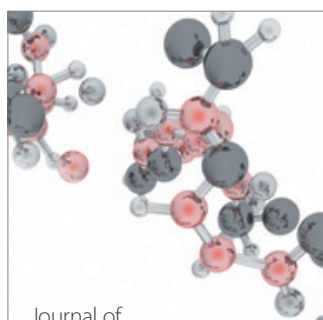

Analytical Methods

in Chemistry

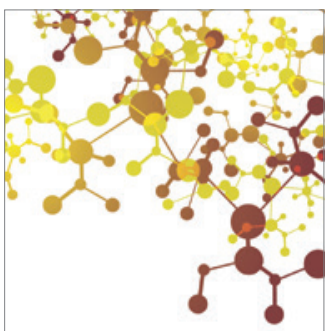

Journal of

Applied Chemistry

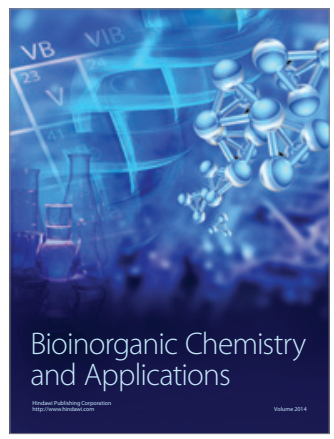

Inorganic Chemistry
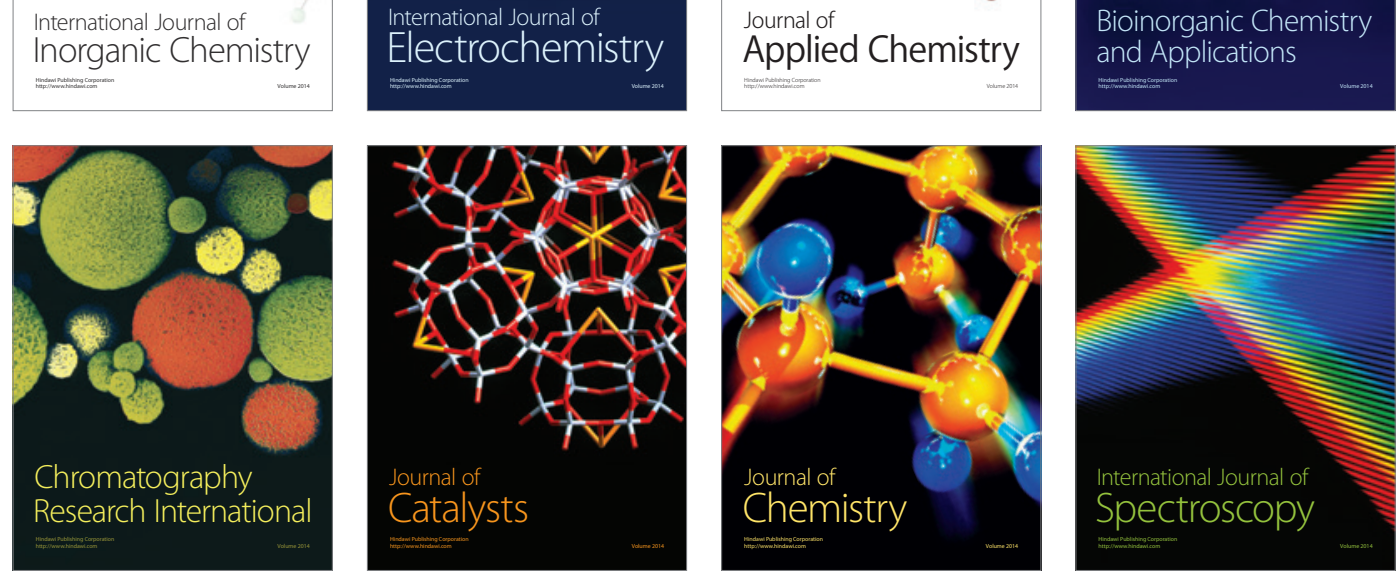